Michelle Sikes

DrM Sikes, Pennsylvania

State University, State

College, PA, United States

of America;

Email: mxs1600@psu.edu

DOI: http://dx.doi.

org/10.18820/24150479/

aa50i2.1

ISSN:0587-2405

e-ISSN: 2415-0479

Acta Academica - 2018 50(2):

12-33

(c) Creative Commons With Attribution (CC-BY)

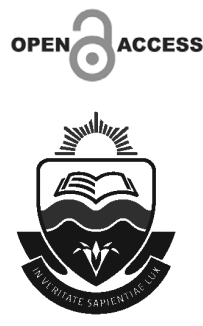

\section{Ousting South Africa: Olympic clashes of 1968}

First submission: 1 August 2017

Acceptance: 29 July 2018

South Africa modified its sport policy, though not its national policy of apartheid, prior to the 1968 Mexico City Olympic Games. Black and white South African athletes would compete as one team at the Olympics for the first time. This reversal of its previous allwhite policy persuaded the majority of $10 \mathrm{C}$ members to accept South Africa's participation at the 1968 Olympics. African nations were the first to withdraw in protest. Taking this stand, despite South Africa's concessions, they sought nothing less than the end of apartheid itself. Recognising that a detailed historical interrogation can shed light on the struggles, politics, limitations, and achievements of social justice in and through sport, this article demonstrates when and how these different visions of social justice emerged, gained traction, and were resisted when it came to apartheid South Africa.

\section{Introduction}

"South Africa does not need to fear that the international sports federation would try to stop her going to [the 1968 Olympic Games in] Mexico," crowed Frank Braun, President of the South African National Olympic Committee (SANOC). ${ }^{1}$ Elated by the

1 The South African Olympic and Commonwealth Games Association (SAOCGA) changed its name to the South African National Olympic Committee (SANOC) after South Africa left the Commonwealth in 1961. For consistency, this article will refer to it as SANOC throughout. 
International Olympic Committee's (IOC's) decision to invite South Africa to the 1968 Mexico City Olympics, Braun could not foresee the authority of the "senior body" being countermanded. He rebuked "the African countries who wanted to boycott the Games [as] cutting off their noses to spite their faces" ("No Fear Over Mexico - Braun," Rand Daily Mail, 18 Feb 1968: 1). Braun predicted, "the size of the Springbok contingent [at the 1968 Games] will total more than all these African states together" ("Braun Hopes for Boycott to be Lifted," Rand Daily Mail, 21 Feb 1968:1).

By the start of 1968, when Braun made this pronouncement, a panoply of apartheid law divided South Africa. ${ }^{2}$ White-dominated racial segregation had long been imposed, which encroached on sport in various ways. South Africa, one of the founding members of the world's cricket governing body, never played cricket against the three black members - India, Pakistan, or the West Indies - before leaving the Commonwealth in 1961 (Gemmell 2004). From 1908, when the country officially debuted at the Olympic Games, until 1960, South Africa's Olympic teams had been comprised of white athletes (Nauright 1997). The 1934 British Empire Games were to be hosted in Johannesburg; however, presaging what was to come in the second half of the $20^{\text {th }}$ Century, protests against South Africa's racial policies saw the games shifted to London (Archer \& Bouillon 1982). Access to beaches, tennis courts, swimming pools, and running tracks, long rationed by race, was controlled with increasing strenuousness after apartheid came into place.

Article 1 of the Olympic Charter enshrined freedom from discrimination along lines of race, religion, or politics. ${ }^{3}$ South Africa's racially segregated clubs, leagues, and governing bodies, which underpinned unequal provision of facilities and sports opportunities, patently violated the Charter's fundamental rule. Yet, in 1968, the IOC allowed South Africa to compete at the Mexico City Olympic Games, lifting the suspension it had imposed ahead of the Tokyo Games of 1964. To nations across Africa, South Africa's return to Olympic competition was unconscionable.

Within the historiography of South African sport history, much has been written about race, politics, and the struggle against apartheid in international sport (Brickhill 1976; Archer \& Bouillon 1982; Jarvie 1985; Kidd 1988; Nixon 1992; Bose 1994; Keech and Houlihan 1999; Booth 19971998 2003; Cornelissen 2011). From the late 1950s, sport became an arena of opposition to apartheid, and isolation increasingly the weapon of choice. South Africa's most popular

2 Under apartheid, South Africans were categorised into four "racial" groups: black, Indian, coloured, and white. Throughout this article, the term "black" refer will refer to all South Africans who were not classified as "white." Quotation marks indicate the socially constructed nature of these categories.

3 In 1968, Article 1 of the IOC's Charter disallowed discrimination by race, religion, or politics. This has been extended to seven "Fundamental Principles of Olympism." See: "Olympic Charter", IOC, www.stillmed.olympic.org/Documents/olympic_charter_en.pdf 
sports of rugby, football, and cricket continue to attract significant scholarly attention, and the boycott of South Africa in sport influences the historical record of each (Grundlingh et al. 1995; Nauright 1997; Black \& Nauright 1998; Desai et al. 2002; Odendaal 2003; Alegi 2004; Gemmell 2004; Murray \& Merrett 2004; Alegi \& Bolsmann 2010; Bolsmann 2010, 2013). Fine-grained historical studies have been made of the anti-apartheid activity of particular organisations, such as the Olympic Project for Human Rights (OPHR) (Blackman 2012), the South African Council on Sport (SACOS) (Booth 1997 1998), and of the men who led and shaped international sport during the anti-apartheid boycott era (Guttmann 1984; Macintosh and Hawes 1992; Cantelon and McDermott 2001; Keech 2001; Smith 2006).

The work of SACOS has received significant attention. Formed in the early 1970 s by non-racial sports organisations within South Africa, SACOS was the domestic sports wing of the anti-apartheid movement (Booth 1997 1998). Under the banner of "no normal sport in an abnormal society", SACOS supporters were forbidden to take part in any form of sport that involved "racialism" or "multiracialism" (Booth 1998: 150). SACOS's guiding principle of non-collaboration was intended to induce real change in South African society, not only in the realm of sport, but by ending apartheid's inhumanity completely. In this regard, its political philosophy has been cast as revelatory, compared with the sporting world's previously blinkered focus on simply reforming sport in South Africa. Booth (1997: 54) contends that, until SACOS's intervention in the 1970s, the "sole objective of the international community's boycott was to integrate South African sport." Pointing out the widely held notion that sport was not to become involved in political imbroglios, he argues that SACOS was the first sport organisation to embrace the boycott not only as a strategy against apartheid sport but also against apartheid per se.

However, SACOS was not the first sport organisation to fight for that more important objective. In the decade prior to SACOS's formation, competing perspectives emerged within the international community regarding South Africa's isolation from international sport. For some, relieving sport of apartheid was indeed the sole objective. White establishment figures held to this more modest vision, urging acceptance of racially discriminatory practices within South Africa so long as the country sent black and white athletes to the Olympics. Other members of the international community, however, harboured greater ambitions, which should be given their due. African nations were prepared to withhold athletic prowess and forego Olympic glory in 1968 for the purpose of jettisoning white minority rule from the continent. These countries did not boycott the 1968 Mexico City Games simply to integrate South African sport. They did so to rid Africa of apartheid entirely. 
In keeping with this special issue's theme of social justice, this article analyses when and how these different visions emerged, gained traction, and were resisted when it came to the "South Africa question" in the late 1960s. My focus falls on institutions, politics, and high-level diplomatic manoeuvring in Olympic sport, but the article is grounded in the campaigners' concern for the social injustices perpetuated on the vast majority of South Africans during apartheid. Representatives of newly independent African states' National Olympic Committees (NOCs) pressed their vision of social justice for South Africa, which was about more than sport.

As Frank Braun's contempt of their boycott threat suggests, African nations were perceived as less powerful than those with longer histories of Olympic involvement. African NOCs gradually gained greater autonomy and recognition during the 1950s and 1960s; however, this did not necessarily mean admission of new members from these countries to the IOC itself (Charitas 2015). In 1968, of the IOC's 72 members, only one was a black African, Sir Ade Ademola, of Nigeria. The other two African IOC members, both white, hailed from South Africa and Kenya. This relates to the second theme of this special issue, subalternity. Following James Mills's (2005) Subaltern Sports, subalternity is understood in a wide sense. Mills defines the term "subaltern" as the "dominated party in any power relationship" (2005:1). He explains that the importance of the concept lies in its emphasis on subaltern actors' agency, despite the structures of power that circumscribe their autonomy. The idea is that the subaltern is not entirely at the behest of the more powerful party and maintains interests, values, and ideas that cannot be controlled. This leaves open the possibility of resistance and opposition, rendering the dominant group's control precarious. In the 1960s, African nations' sport bodies and officials were subalterns within the power relationships of the IOC. Yet the process of negotiating South Africa's involvement in the 1968 games revealed both the limits of that power and the range of objectives that were to be achieved by sanctioning South Africa in the realm of sport in the late 1960s.

\section{Optimism for Olympism: "outward-looking" changes}

By the end of 1967, South Africans were increasingly optimistic that suspension from the 1964 Tokyo Olympic Games might be dismissed as a blip. The IOC had not expelled South Africa from the Olympic movement and, therefore, it was technically eligible to participate in the Mexico City Games of 1968. Confidence in returning to the Olympic fold rose especially after Prime Minister John Vorster announced his "outward-looking" sport policy in April 1967. He promised that South Africa would send a single team of black and white athletes to the 
Olympics, which would travel and live together and compete as one under the South African flag.

The IOC heralded this "liberalised" sport policy. IOC President Avery Brundage called it a "considerable advance" ("IOC Probe, Situation Fluid, says Brundage,"

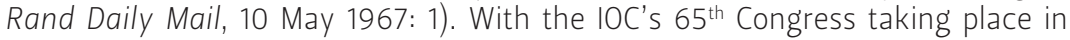
Teheran one month after Vorster's announcement, in May 1967, his concessions engendered goodwill within Olympic circles at an opportune moment. At that meeting, SANOC duly pledged that, if invited to compete, a "massive team of Black and White athletes" would represent South Africa at the games (IOC Minutes, Tehran, 3 May 1967; "S. Africa Pledges Mixed Games Team," Daily Nation, 9 May 1967: 25). Even to anti-apartheid leader Dennis Brutus, these changes were promising. Arrested, shot, imprisoned and exiled from his native South Africa for his anti-apartheid efforts in sport, Brutus conceded: "My first reaction on reading the concessions was that they were really quite spectacular. Compared to South Africa's previous position they represented a real advance" (in Bose 1994: 71).

Previously, South Africa had been unendurably stubborn. In 1963, South Africa refused to send an Olympic team composed of black and white athletes to compete as one at the Games. In 1964, South Africa's Olympic Committee preferred to miss the Tokyo Games than to publicly denounce apartheid policy in sport. Early in 1967, faced with the prospect of South African coloured cricketer Basil D'Oliveira playing for England against his nation of birth during an upcoming tour, South Africa's Minister of the Interior stated that the government would remain "inflexible and immovable" in its stand over racially mixed international sports teams competing against white South Africans (George Oliver, "Olympic Probe Permits," Rand Daily Mail, 10 Feb 1967: 1). Compared with this rigidity, Vorster's stated willingness to allow a racially mixed South African team to compete at the Olympic Games seemed, to some, deserving of serious consideration.

African NOCs disagreed. This was no "real advance" worthy of plaudits, much less reinstatement at the Olympic Games. Within South Africa, sport was to remain separate and unequal, as Vorster made abundantly clear. "In respect of this principle," emphasised the Prime Minister, "we are not prepared to compromise, to negotiate and we are not prepared to make any concessions" (in Brickhill 1976:22). Rather than hold open trials to determine who would compete at the Olympics, "multi-racial committees" were to select the team on the basis of racially separate trials. Vorster preferred to remain out of the Olympic Games rather than to allow racially mixed trials, and he had no intention of easing apartheid in sports - or any other domain - within the country. Fundamentally, this proposal left the legalised racial discrimination of apartheid intact. 
In response, at the IOC's meeting in Teheran in 1967, African sport officials signed a memorandum reserving their right to withdraw from the 1968 Olympics if South Africa were to be readmitted (IOC Minutes, Tehran, 3 May 1967:100). In agreeing to send a single team with black and white athletes marching under the same flag and in the same uniforms, Prime Minister Vorster's government had given way on details, not apartheid principles, they argued. African nations spurned these concessions as having been made only to meet the exigencies of Olympic rules while apartheid remained unaltered within the country. Under such conditions, if the South African team competed, other African nations would not.

Some IOC members hoped that the findings of the South African Commission might resolve the impasse. Commissions were frequently set up by the IOC to study "special problems". IOC Vice President Lord Michael Killanin of Ireland led the South Africa Commission or, as it would come to be called, the "Killanin Commission". He was joined by Reginald Alexander, of Kenya, and Sir Ademola, a past president of the Nigerian Olympic Association, the first black African to serve as Chief Justice of Nigeria, and the first to become a member of the IOC. They were to study and report on the conditions of sport in the country so that the IOC could determine whether South Africa merited an invitation to the 1968 Mexico City Games. The men's brief concerned only whether Olympic regulations could be met, and if black and white athletes had an equal opportunity to take part in the Olympic system - not the government's apartheid policies per se. The three men spent 10 days in South Africa, from 7 to 17 September 1967, touring sports facilities and interviewing athletes and officials. Their itinerary involved visits to several cities and sections of the country and interviews with some 50 sport organisations ("IOC Mission to Visit SA Next Month," Rand Daily Mail, 14 Aug 1967: 1).

The commission's 119-page report was officially released to IOC members on 30 January 1968. The authors abided by instructions not to present explicit recommendations; however, the tone of the report was favourable to South Africa's reinstatement at the Olympics (Report of the IOC Commission on South Africa, British Olympic Association Archives, GB 2381 BOA/IOC/POL/2/3, Feb 1968). It highlighted "overwhelming evidence" that "sportsmen of all communities" in South Africa accepted SANOC's proposed method of team selection by multi-racial committee and separate trials (IOC Newsletter No. 5, "About the South African Team," Feb 1968; "All Races Accept Olympic Plan," Rand Daily Mail, 31 Jan 1968: 2). The report also showed that South Africa fell short of full acceptance of Olympic ideals, with strict segregation in sports clearly being maintained within the country.

IOC members in Grenoble were given two days in which to digest the report before the issue came up for discussion early during the IOC's $66^{\text {th }}$ session (IOC 
Minutes, Grenoble, 1-6 Feb 1968). South Africa's participation at the games was the main item on the agenda. However, with 16 delegates absent, by a small number of votes - one press report stated 27 to 26 , another 28 to 25 - it was decided that, for all to have a say on this important issue, IOC members would cast their vote by mail, rather than in Grenoble ("Games Decision on Feb. 15," Rand Daily Mail, 3 Feb 1968: 3; Fred Labuschagne, "Optimism on SA Olympics Hopes," Rand Daily Mail, 14 Fen 1968: 1).

Accompanying the ballot papers was the IOC Executive Board's resolution, which endorsed SANOC's proposal (IOC Newsletter No. 5, "About the South African Team," Feb 1968). ${ }^{4}$ IOC members were pressed to agree that, in light of South Africa's agreement to send a racially mixed team, the country had made sufficient progress to be readmitted to the Games. South Africa's return was also premised on its sports bodies' "continued" opposition to apartheid policy, with the South African Olympic Committee expected to strive "vigorously" to lift all racial discrimination from amateur sport (IOC Newsletter No. 5, "About the South African Team," Feb 1968; "The Politics of Sport," Rand Daily Mail, 16 Feb 1968: 5). On that understanding, the IOC was charged with reconsidering the question by the end of 1970 .

This formulation reflected the limited ambitions of the IOC's leadership. The endorsement contained elements that had characterised the debate five years earlier: reluctance to make a truly binding decision and blinkered concern about racial discrimination in sport, without regard for apartheid as a whole. Despite its grudging and temporary concessions, the South African government's position on apartheid in sport at home had remained extremely clear and consistent over the previous years: doing away with separation by race in sport within the country would not be tolerated. In addition, the IOC's terms indicated that sports organisations in South Africa should "continue" to oppose apartheid actively. As a South African paper pointed out, the South African sport representatives

4 The full resolution went as follows: "Having studied the report of the Commission of South Africa, the IOC notes with grave concern that the racially discriminatory internal policy of the South African Government prevents the National Olympic Committee of that country from achieving fully the aims of the IOC and fundamental Principle One of the Olympic Code. It is, however, encouraging that positive efforts by the South African National Olympic Committee have resulted in a firm undertaking to implement the proposal announced at the IOC session in Teheran in May 1967, whereby a multi-racial team will be selected on merit. It now resolves that the South African National Olympic Committee may enter a team which conforms with the fundamental Principle One in the Olympic Games in 1968 in Mexico and on the understanding that it continues vigorously its efforts to have all forms of racial discrimination in amateur sport removed and the IOC will reconsider the question by the end of 1970" (IOC Newsletter No. 5, "About the South African Team," Feb 1968). 
in Grenoble, like their predecessors at IOC meeting's throughout the 1960s, had hitherto indicated no disposition to argue with the government on the application of its policies in sport ("Dim Olympic Prospect," Rand Daily Mail, 6 Feb 1968: 10). Nonetheless, to the IOC's Executive Board, incremental steps in sport policy befitted South Africa's return to the Olympics in 1968.

Two days before the deadline for tallying the votes, IOC Secretary General John Westerhoff made it known that 65 of 71 votes had been submitted, with Cuba, Chile, Venezuela, Uruguay, Senegal and Argentina yet to return a ballot (Fred Labuschagne, "Optimism on SA Olympics Hopes," Rand Daily Mail, 14 Fen 1968: 1). A majority in favour was required to admit South Africa. As IOC delegates, and the world, waited for votes to be returned and counted, African NOC officials reiterated that even if a majority of the IOC opted to invite South Africa to Mexico City, the republic's chances in fact hinged on the seriousness of their threats to boycott. Notice of this had been given repeatedly, including in December 1967, when delegates of the Supreme Council for Sport in Africa (SCSA) announced at their General Assembly meeting in Lagos that the council intended to do everything possible to keep South Africa from the Olympics ("Africans May Boycott Games," Rand Daily Mail, 7 Dec 1967: 1). Andre Hombessa, CongoBrazzaville's Minister of the Interior, had declared, "no matter what South Africa does to cover its apartheid policy, it will not be acceptable to African states" (ibid). African states were set to boycott because of the absence of racial equality in South Africa, regardless of changes to apartheid in sport.

African delegates also articulated their resistance to South Africa's reinstatement at the 1968 IOC meeting in Grenoble. Jean-Claude Ganga, of Congo Brazzaville, informed delegates once again that if the IOC's postal ballot returned South Africa to the games, African nations were likely to boycott ("Boycott if SA Wins Vote on Olympics," Rand Daily Mail, 5 Feb 1968: 1). He explained that a meeting of the SCSA's Executive Committee would be called and that this sport governing body was authorised to recommend action to the SCSA's 32 members. This, he warned, would "almost certainly result in a boycott of the games by African nations" (ibid). Tanzanian delegates in Grenoble confirmed that they would abide by this decision; if the SCSA recommended boycotting, Tanzania would withdraw ("US Athletes Protest on SA Role," Rand Daily Mail, 9 February p. 13). Grenoble-based African delegates further made known their intention to persuade nations beyond the continent to boycott, should South Africa be readmitted, estimating that perhaps half of the 123 Olympic nations could be won to the cause ("Olympics - SA Knows Tonight," 15 February 1968, Rand Daily Mail: 1). The Soviet Union, too, was thought to support the boycott but the catalyst and object of the protest was clear. Conditions beyond sport in South Africa mattered to the African nations that would lead a concerted withdrawal. 
Some IOC members discounted this as bluster. IOC General Secretary Westerhoff believed that African nations would compete, regardless of the outcome of the vote. "I know they have threatened to walk out. But I can tell you that at least three of the major African athletic nations have given an assurance that they will go to Mexico - even if South Africa is there." He insinuated that countries with little to lose by not participating were the ones issuing the threats. "Those nations who are doing the talking have no interest - and in some cases no athletes" (Fred Labuschagne, "Optimism on SA Olympics Hopes," Rand Daily Mail, 14 Feb 1968: 1). South African IOC delegate Reginald Honey called the boycott threat a "gigantic bluff" ("Back for Good' is Experts' Reaction," Rand Daily Mail, 16 Feb 1968: 1). The day after the vote was decided, Honey felt confident enough to declare: "I don't think one single country will boycott the Games" ("Back for Good' is Experts' Reaction," Rand Daily Mail, 16 Feb 1968: 1). Denis Mclldowie, one of SANOC's delegates in Grenoble, shared this certainty. He did not expect any boycotts, but if any materialised, they would "not make the slightest difference to the IOC's decision" (ibid).

The results of the IOC's vote were announced at 8:00pm on 15 February 1968 in Grenoble's new town hall ("Olympics - SA Knows Tonight," 15 February 1968, Rand Daily Mail: 1; "SA Back in Games," Rand Daily Mail, 16 Feb 1968: 1). Votes had been cast by 66 of the IOC's 71 members. If a 33-33 tie ensued, IOC President Brundage would provide the deciding vote ("Olympics - SA Knows Tonight," 15 February 1968, Rand Daily Mail: 1). This would not be necessary. By an absolute majority - 36 in favour, 25 against, one abstention, and four not valid - the IOC voted in favour of South Africa's participation at the 1968 Mexico City Olympics (IOC Minutes, Mexico City, 7-11 October 1968)..$^{5}$

\section{Reactions to South Africa's reinstatement}

Still in Grenoble for the Winter Olympics, a dozen IOC members, including Brundage, and a throng of reporters were present to hear the IOC's Secretary General Westeroff read the result ("S.A. Back in Games," Rand Daily Mail, 16 Feb 1968: 1). Alternating in French and English, Westerhoff emphasised the list of assurances that South Africa had given: 1) South Africans, black and white, would form one team to represent the country; 2) black and white athletes would travel together to the games; 3) South Africa's entire team would wear the same uniform, stay together, and march as one under the South African flag; 4) white and black South Africans would compete against each other at the Olympic Games and other

5 The breakdown of the vote was not initially stated in the $\mathrm{IOC}$ minutes. The decision to release the numbers was made at the 1968 IOC meeting in Mexico City. 
international sports events; and 5) an equal number of black and white officials, under the chairmanship of the President of SANOC, would select participants ("S.A. 'Yes' on Five Points," Rand Daily Mail, 16 Feb 1968: 1). In Grenoble, reaction to the news was mixed, with some in favour of the decision, others opposed. Brundage thought the IOC deserved praise while representatives from Ethiopia and Algeria responded that their nations would withdraw in protest ("Africa Verdict Roils Olympics," Chicago Tribune, 17 Feb 1968: 1). Representatives from the USSR castigated the result but avoided speaking directly about withdrawal, despite having indicated previously that a boycott would be forthcoming if South Africa were admitted.

Brundage and others of his ilk believed that South Africa's promises of a multi-racial Olympic team, and the desire of black South African athletes to compete at the Games on SANOC's terms, justified South Africa's reinstatement. Brundage also recognised that a single South African Olympic team, comprised of black and white athletes, conferred global approbation on the IOC as a catalyst of social justice. After the vote, he exulted, "it was only the power of the Olympic movement that could have secured this change, and this is the first time by any organisation that anything has been accomplished for non-whites in South Africa" ("Press Conference," IOC Newsletter, 16 Feb 1968). Presenting South Africa's concessions as a breach in a hitherto impenetrable wall, Brundage described the IOC as "having become the most important social force in the world today" (ibid). Westerhoff was pleased that South Africa could go to the Mexico City Games because it meant the IOC had "got the Black man of South Africa into the Olympics". He congratulated his institution on "having shown that we are against discrimination" ("Decision Pleases IOC," Rand Daily Mail, 16 Feb 1968: 1). For the white Olympic establishment, the objective of placing a veneer of nondiscrimination over South Africa's sporting apartheid had been achieved.

News of South Africa's reinstatement flashed over British television and radio that evening ("News was Flashed on TV Screens," Rand Daily Mail, 16 Feb 1968: 1). Radio South Africa broke into programmes with the news, which was splayed across newspaper headlines the following day. Articles announcing South Africa's reinstatement dominated the front page of the Rand Daily Mail. Headlines such as, "'We are Back for Good,' is Experts' Reaction," "Decision Pleases IOC," "SANROC [South African Non-Racial Olympic Committee] will do all it can to Block SA," and "Non-White Athletes Rejoice," indicate the range of reactions to South Africa's reinstatement. Black South African athletes, conservative IOC members, and white establishment South African sport officials celebrated the decision. Prime Minister Vorster was "glad for the sake of our young sportsmen and athletes since they can again take part in the Olympic Games, which is their right and privilege to do" ("S.A. Back in Games," Rand Daily Mail, 16 Feb 1968:1). On the other hand, 
this was not expected to be the final word. As anti-apartheid sport activist Chris de Broglio put it: "The White Mafia on the IOC have obviously decided to throw down the gauntlet. Well, the African countries will pick it up" ("SANROC will do all it can to block SA," Rand Daily Mail, 16 Feb 1968: 1).

Ethiopia and Algeria were the first to announce their withdrawal from the Games (Sapa-Reuter-A.P., "Ethiopia Quits Olympics," Rand Daily Mail 17 Feb 1968:1). Ethiopia's Abebe Bikila, winner of the 1960 and 1964 Olympic marathons, expressed disappointment with the IOC ruling. ${ }^{6}$ His NOC's president, Yidnekatchew Tessema, described the IOC's decision as a "victory for apartheid" (Les Matthews, "Olympic Games In Jeopardy," New York Amsterdam News, 2 Mar 1968: 30). Tessema expected it to force African countries away from the Olympic movement and "towards other athletic organisations where apartheid does not exist" (Special Correspondent, "Olympics Decision Delights South Africans," The Irish Times, 17 Feb 1968: 1). Jackson Mutala, President of the Kenya Boxing Association, explained his association's views: "What's the point of Kenya sending a side when other African nations are boycotting the Games? This [would] show lack of sympathy with our South African brothers" "Aftermath of the boycott," Daily Nation, 21 February 1968: 23). For African sport leaders and many African athletes, competing in an arena that tacitly accepted legal racial discrimination would nullify any victory.

Ghana, Mali, Tanzania, Uganda, and Egypt (then known as the United Arab Republic, UAR) were the next to announce that they, too, would not send athletes to Mexico. From New York came word that the American Committee on Africa hoped American athletes would "boycott in solidarity with African nations against apartheid" ("Africa Verdict Roils Olympics," Chicago Tribune; 17 Feb 1968: 1). Syria and Iraq were the first countries outside of Africa to announce their decision to boycott alongside the 10 African nations that had, by then, declared their intention not to compete. On 18 February 1968, three days after the announcement of South Africa's return to the Games, the SCSA's chairman, as promised, called an extraordinary meeting to discuss a boycott by all of its 32 member states ("S. Africa Denies London Report of Withdraw," Times of India 19 Feb 1968: 11).

A semi-autonomous subsidiary of the Organisation of African Unity (OAU), the SCSA had been established in December 1966 to coordinate sport in Africa. One of its founding resolutions was to obtain the expulsion of South Africa from the Olympic movement (Booth 1998). Prior to the SCSA's meeting, the UAR raised the issue at the $10^{\text {th }}$ session of the Ministerial Council of the OAU in Addis Ababa ("5 More African Nations Join Boycott of Olympics," 1968 New York Times, 18 Feb

6 Abebe Bikila's life has been chronicled in Judah (2009) and Rambali (2006). 
1968: 172). OAU ministers praised the states and national Olympic committees that had opposed the IOC's decision. Their recommendation to the SCSA was that African states, as a collective, boycott the games ("Ministers of Africa Rap IOC Ruling," Chicago Tribune, 25 Feb 1968: B6). The OAU ministers' resolution also made ending apartheid itself the condition upon which African nations' participation should turn. "So long as [South Africa] persistently pursues the inhuman policy of apartheid, all member states of the OAU, and all other states and sports organisations that are inspired by the same racial equality, should refrain from participating in the Games," was its official statement ("Africans Pressing Boycott of Olympics," New York Times, 25 Feb 1968: S1). As long as South Africa continued with apartheid, changes to its sport policy alone would not satisfy the OAU.

Brundage went to work defending the IOC's decision. He urgently contacted the SCSA, advising against a boycott and protesting that sport and politics must be kept separate ("Olympic Boycott," Rand Daily Mail, 27 Feb 1968: 12). He cautioned that if the boycott were to keep South Africa from the Olympics, it would hurt the black South Africans who wished to participate ("African Supreme Council Approves Olympic Boycott," The Times of India, 27 Feb 1968: 14). Increasingly alarmed by the potential disruption to their games, the Mexico City Olympic Organising Committee sent two representatives, Dr Eduardo Hay and Roberto Casellas, to Brazzaville to appeal in person to the SCSA Executive Committee to call off the boycott. The Mexicans were to highlight the occasions on which Mexico had stood in solidarity against South African apartheid and communicate that Mexico had voted against the decision to reinstate South Africa ("Mexico Hopes To Halt African Games Walkout," Chicago Daily Defender, 26 Feb 1968: 24; "African Supreme Council approves Olympic Boycott," The Times of India, Feb 27 1968: 14). Frank Braun too sent a letter of appeal to boycotting nations to reconsider their decision ("Mexico Embarrassed by Olympics Dispute," The Irish Times, 22 Feb 1968: 5).

On 25 February 1968, two weeks after South Africa's reinstatement, the SCSA's Executive Committee met in the Congolese capital of Brazzaville. The Executive Committee, representing 32 African nations, was made up of 11 members from 10 nations - Congo-Brazzaville, Nigeria, Mali, Togo, Gabon, Uganda, Malagsy Republic, Tunisia, Ghana, and Guinea. After two days of discussion, the executive committee, with regrets to Mexico, voted unanimously to ask all African NOCs to withdraw from the 1968 Games ("Olympic Boycott," 27 Feb 1968: 12; "32 African Countries Vote Olympic Boycott," Chicago Daily Defender, 27 Feb 1968: 24). SCSA Secretary-General Jean-Claude Ganga summed up the thinking of the Brazzaville delegates: "The black men of South Africa would be like trained monkeys who would be shown at the fair and who would go back to the forest 
once the party was over" (in Lloyd Garrison, "African Shock Waves," New York Times, 28 Feb 1968: 57). As president of the Nigerian Olympic Games Committee Abraham Ordia put it, "what South Africa does in sports outside her borders is not as important as what she does inside her borders" ("5 More African Nations Join Boycott of Olympics," New York Times, 18 Feb 1968: 172).

Within two weeks, almost all members of the SCSA had confirmed their intentions to boycott. Diverging from the IOC Executive Board's stance on what social justice entailed, the real issue, these African nations averred, was not sanctioning South Africa's promise to send a racially diverse Olympic team on the basis of separately contested trials. It was ending South African apartheid. Boycotting the Games in anti-apartheid solidarity was also an opportunity for African states to play a serious role in international politics around a cause that unified them (Cornelissen 2011). For states that lacked other forms of leverage, the sport boycott was an effective way to fight for social justice in South Africa.

Abetting their efforts was control over the world's access to some of its premier athletes. Although African nations had won only a handful of the medals on offer at the 1964 Olympic Games, they were becoming increasingly important on the track. Kenya was considered to have one of the best Olympic teams in the world and planned to send at least 50 athletes ("Kenya, Sudan and Iraq Join Boycott of Summer Olympics," New York Times, 21 Feb 1968: 39; "Kenya--and Keino--out Mexico Olympics," The Irish Times, 21 Feb 1968: 5). ${ }^{7}$ This included Commonwealth champions Naftali Temu and Kipchoge Keino, favourite in the 5000 metres, and the 1964 Olympic bronze medallist in the 800 metres, Wilson Kiprugut, as well as Philip Waruinge, the Commonwealth Games featherweight boxing champion. Ethiopia, Senegal, Ghana, and the Ivory Coast also had prospective Olympic medallists. By 1968, more than 30 African nations were eligible to participate in the Olympics. Any games absent these African teams would be tarnished.

In the wake of the IOC's decision, within South Africa, jubilation, if not unanimous, was widespread. But the stage was set for a contrarian outcome. The minute sliver of the black elite athlete South African population would for the first time in history be allowed to compete on an Olympic stage. White, black, coloured, and Asian athletes would, for the first time, be permitted to compete together beneath the springbok, the symbol of South African sport. A Pyrrhic victory for that tiny portion of the population came at the grave cost of continuing the apartheid status quo generally. African nations clearly recognised

7 The 1968 Mexico City Games would indeed be a breakthrough for male Kenyan distance runners. They won three gold medals (1500 metres, 10,000 metres, and the 3000 metres steeplechase), four silver medals (800 metres, 5000 metres, 3000 metres steeplechase, and the $4 \times 400$ metre relay), and one bronze medal (5000 metres). 
the contradiction and sought the larger victory as a united front. Guided by a different vision of social justice, the SCSA pressed for more substantive change beyond the concessions that the IOC had managed to obtain.

\section{The IOC succumbs}

Considerable world support greeted the SCSA's boycott threat. African nations' withdrawal was buttressed by states from Asia, the Middle East, and the Caribbean. The Mexico City Organizing Committee became increasingly insistent that South Africa should not be allowed to take part (Brewster \& Brewster 2010). Led by chairman Pedro Ramírez Vázquez, the committee sent a delegation to Chicago to lobby Brundage personally that South Africa's invitation should be rescinded (ibid; "Olympics Talks Called," The Times, 2 Mar 1968: 1). The Soviet Union was now the main concern. If it backed out of the games, so too would other Eastern European states. Soviet IOC delegates had lobbied strenuously against South Africa in the past and promised to support a boycott, should South Africa be admitted.

On 7 March 1968, the NOC of the Soviet Union declared that the IOC must convene an emergency session to decide on South Africa, else the Soviet Union would have to reconsider its participation in the games. While not an unequivocal threat to boycott, the Soviets were signalling that they were, potentially, willing to forego Olympic competition (Maule, Sports Illustrated, 29 April 1968). They expressed solidarity with the nations that had withdrawn and voiced sympathy with the Mexico City hosts (Reuters, "Soviet Asks I.O.C. to Bar South Africa," NYT, 6 Mar 1968). In the context of the Cold War, the end of colonial rule had given rise to non-aligned states, while South Africa continued to staunchly support Western interests. This translated to the Soviet Union favouring African demands for the barring of South Africa and the United States and other Western nations supporting South Africa's continued Olympic participation.

There was, however, support for an Olympic boycott in the United States. The American Committee on Africa issued a joint statement in solidarity with the nations that planned to boycott. Prominent athletes in its membership held that allowing South Africa at the Olympics violated the integrity of the games ("Wilt, Luke Among 60 [sic] Athletes Supporting Boycott," Philadelphia Tribune, 16 April 1968: 15). Labelling Vorster's sport policy "a fraud," Jackie Robinson, an supremely talented athlete who broke the colour line in professional baseball in the United States, said that, "If the IOC accepted South African tokenism, it would appear that international sportsmen condone South African apartheid policy" ("US Athletes Protest on SA Role," Rand Daily Mail, 9 Feb 1968: 13). Robinson shared African nations' perspective that social justice demands could not countenance any athlete representing the apartheid state at the Olympic 
Games and urged American athletes to join the protest movement against South Africa's readmission. Activist academic Harry Edwards also called on athletes to boycott the 1968 Games, both to draw attention to racism and the exploitation of black athletes in the United States and in support of the anti-apartheid struggle (interview with Harry Edwards, 4 April 2018; Blackman 2012).

The threat of withdrawal of more than 40 nations, most of them African, and "including one of the Big Two contestants," painted the IOC into a corner ("Olympic Boycott," Rand Daily Mail, 27 Feb 1968: 12). By the first weekend in April, delegates from Mexico, Sweden, Belgium, and elsewhere, were calling for an emergency session of the IOC ("Mexico Asks for an Emergency Session of International Olympic Committee," NYT, 10 Mar 1968). Brundage travelled to Johannesburg, where he conferred with Frank Braun and other SANOC representatives, perhaps in a vain attempt to convince the South Africans to stay home voluntarily ("Mexico without the South Africans," IOC Newsletter, May 1968; "Brundage in South Africa for Meeting," Chicago Tribune, 16 Apr 1968: C3).

The culmination of this activity came the weekend of 20-21 April 1968. The nine-man executive board travelled to Lausanne, Switzerland and held an emergency meeting at the IOC's headquarters, the Chateau de Vidy, overlooking Lake Geneva. There, the IOC Board, consisting of men from France, Mexico, the Soviet Union, Pakistan, Britain, Lebanon, Italy, and Ireland, along with Brundage of the United States, deliberated across an oval table in an oak-panelled conference room (Lloyd Garrison, "Olympic Committee Elders Weigh So. Africa Question," 21 Apr 1968, The New York Times: S1). After two days, their verdict was to poll all IOC members, again. This time, a very different recommendation accompanied the poll, namely, that it would be "most unwise" for South African's team to compete in Mexico. Along with a telegrammed request for each member to vote for a second time came the following statement:

In view of all the information on the international climate received by the Executive Board at this meeting, it is unanimously of the opinion that it would be most unwise for a South African team to participate in the Games of the XIX Olympiad - therefore, the Executive Board strongly recommends that you endorse this unanimous proposal to withdraw the invitation to these Games ("Mexico without the South Africans," IOC Newsletter, May 1968).

The decision taken in February should be reversed, counselled the IOC Executive Board. The board unanimously recommended that South Africa's invitation to the games be withdrawn. Deliberately, no mention was made of apartheid or of boycott threats. Rather, the "international climate" was proffered as a vague 
justification for rescinding South Africa's invitation. The New York Times reported that, according to Brundage, this referred to the "present atmosphere of violence around the world" (Lloyd Garrison, "Olympic Unit, in Reversal," The New York Times, 22 Apr 1968: 1).

Present in Lausanne to hear the decision, SCSA leader Jean-Claude Ganga, "grinning broadly," reportedly congratulated and shook hands with Soviet delegate and IOC Vice President Constantin Andrianov (Maule, Sports Illustrated, 29 April 1968). The Mexican delegation was "jubilant" and NOC chairman Vázquez expressed "deep satisfaction" with the decision (ibid). On the other hand, Frank Braun, hearing the news in South Africa, called the decision a "shocking miscarriage of justice" ("IOC Won't be Reliable," 22 Apr 1968, Chicago Tribune: E1).

With more than 40 nations threatening to boycott if South Africa were to compete and only a slim majority voting for South Africa's readmission in the first place, the clear expectation was for the IOC's membership to fall in line with the recommendations. There was also no precedent of the IOC ever having defied its executive board. The result was indeed 47 in favour of withdrawing South Africa's invitation, 16 votes against and eight abstentions ("Mexico without the South Africans," IOC Newsletter May 1968). On 24 April 1968, two months and eight days after celebrating the IOC's decision to readmit South Africa, Brundage grimly announced the reversal - the IOC recommended that Mexico City rescind its invitation to South Africa. He declared:

It should be emphasised that in adopting this recommendation the International Olympic Committee is not bowing to threats or pressures of any kind from those who do not understand the true Olympic philosophy. Boycott is not a word used in sport circles ("Mexico without the South Africans," IOC Newsletter, May 1968: 149).

Brundage wished to make it clear that these decisions had not been wrought because of pressure from certain groups, nor because the IOC's version of social justice, with sport separate from political imbroglios, warranted reconsideration. This would have given overt recognition to the efficacy and morality of the Africanled, Soviet-favoured boycott. But his were impotent fulminations. The suggestion is inescapable that threats to boycott had forced the IOC to revoke its decision on South Africa. The IOC was bowing to pressure instigated by African nations, made possible by shifts in political power that had been taking place throughout the 1950 s and 1960 s and by the strength of an alternative vision of what constituted social justice in Africa. This was not lost on the African National Congress (ANC) operatives who published Mayibuye, an underground bulletin. In the week after the IOC announced the reversal of its decision, that publication declared the ANC's "sincere appreciation of the principled stand taken by the Supreme Council of African Sports [sic] and all those countries and individuals who promised not to 
participate in the Mexico City Games if South Africa were admitted" ("A Victory for Africa," 27 April 1968: 3).

The IOC's leadership demonstrated profound insensitivity to the tenor of the times by encouraging South Africa's return to the Olympic fold in 1968. At a point in history when the previously disenfranchised were beginning to make their voices heard, this committee chose to reinstate one of the most egregious offenders of human dignity. Out of sync with the politics and moral sensibilities of the decolonised world, the white IOC establishment touted the virtues of a superficially modified sport policy as a meaningful objective, rather than as a gain too tiny to be acceptable. African sport organisations, leaders, and athletes, however, refused to obscure the larger issues of morality involved.

\section{Conclusion}

The IOC was riven during the late 1960 s over the "South Africa question". African nations' sports officials held firm in their mission to keep South Africa from the games, while the white IOC establishment sought to accommodate it. Yet both cast their actions in terms of achieving social justice for black South Africans. For newly independent African countries, competing against South Africans under the aegis of Olympic fraternity was neither benign nor apolitical. Contrary to claims that before the 1970s, the sole objective of the international community's boycott was to integrate South African sport, at the heart of African delegates' decision to deny South Africans access to the games was the larger moral challenge that white minority rule posed to other African states.

The leadership of the IOC, on the other hand, did indeed attempt to cast South Africa's institutionalised racism as beyond the pale of sport. It placed faith in SANOC's promises to send a multiracial team to the Games. The IOC championed as paramount the concessions from the South African government that a handful of black South African athletes could compete at the 1968 Olympic Games, conditional on segregated trials. African nations, subalterns in the power relationships within the IOC, were ultimately able to enforce their understanding of social justice over that of the establishment IOC, led by Brundage. Black South African athletes could not take part in the Olympic Games but the battle against apartheid was joined.

In hindsight, issues of social justice in sport may look straightforward. However, as this article has sought to demonstrate through detailed historical reconstruction of how and when different visions of moral action emerged, gained traction, and were resisted when it came to one episode of apartheid South Africa's sport history, struggles over social justice in and through sport are replete with ambiguity, complexity, and conflict. 


\section{Bibliography}

\section{Primary sources:}

9 African nations to joIn Games boycott (1968) Rand Daily Mail, 19 Feb: 1 A VICTORY FOR AFRICA AND THE TRUE SPIRIT OF SPORT (1968) Mayibuye: Bulletin of the ANC, Vol. 2, No. 17, 27 April: 3-4.

African Supreme Council approves Olympic boycott (1968) The Times of India, Feb 27: 14.

AfRICANS May BOyCott Games (1967) Rand Daily Mail, 7 Dec: 1

Aftermath of the Boycott... No Comment yet Says Kenya's Olympic Chief (1968) Daily Nation, 21 Feb: 23.

AlL RACES ACCEPT OLyMPIC PLAN (1968) Rand Daily Mail, 31 Jan: 2

An IntervieW With President Brundage (1968) IOC Newsletter, No. 8(May): 151-154.

BACK FOR GOOD' IS EXPERTS' REACTION (1968) Rand Daily Mail, 16 Feb: 1.

BOYCOTT IF SA WINS VOTE ON OlYMPICS (1968) Rand Daily Mail, 5 Feb: 1

BRAUN HOPES FOR BOYCOTT TO BE LIFTED (1968) Rand Daily Mail, 21 Feb: 1

DECISION PLEASES IOC (1968) Rand Daily Mail, 16 Feb: 1.

Dim OLYMPIC PROSPECT (1968) Rand Daily Mail, 6 Feb: 10.

ETHIOPIA QUITS OlYMPICS (1968) Rand Daily Mail, 17 Feb: 1.

GAMES DECISION ON FeB. 15 (1968) Rand Daily Mail, 3 Feb: 3

GARRISON L (1968) African shock waves. New York Times, 28 Feb: 57.

HOSTILITY TO S.A. IS ON INCREASE (1969) Rand Daily Mail, 2 Dec 1969: 8.

IOC PROBE, SITUATION FLUID, SAY BRUNDAge (1967) Rand Daily Mail, 10 May: 1

IOC MAN DEFENDS DECISION ON SA (1968) Rand Daily Mail, 21 Feb: 1

IOC MISSION TO VISIT SA NEXT MONTH (1967) Rand Daily Mail, 14 Aug: 1.

LABUSCHAGNE F (1968) Optimism on SA Olympics hopes. Rand Daily Mail, 14 Feb: 1

MAULE T (1968) Switcheroo from Yest to Nyet. Sports Illustrated, 29 April. <https:// www.si.com/vault/1968/04/29/609829/switcheroo-from-yes-to-nyet> MAULE T (1968) A flare in the dark. Sports Illustrated, 3 June 1968.<https://www. si.com/vault/1968/06/03/609497/a-flare-in-the-dark\#>

MeXico SSKS For an EMERgenCy SESSION of InTERnational Olympic CommitTEe (1968) The New York Times, 10 Mar: S13.

Mexico Without the South Africans (1968) IOC Newsletter, No. 8(May): 147-150. MinUtes OF THE $65^{\text {TH }}$ SESSION OF THE InTERnational Olympic CommitTee (1967) Bulletin du C.I.O., No. 98-99, 3-8 May. 
Minutes OF THE $66^{\text {Th }}$ SESSION OF THE InteRnational Olympic CommitTee (1968) IOC Newsletter, No. 6-7, 1-6 Feb.

MinUtes OF THE $67^{\text {Th }}$ Session OF THE INTERnational Olympic CommitTeE (1968) IOC Newsletter, No. 15, 7-11 Oct.

NEWS WAS FLASHED ON TV SCREENS (1968) Rand Daily Mail, 16 Feb: 1.

No FEAR OVER MEXICO - BRAUn (1968) Rand Daily Mail, 18 Feb: 1.

OLIVER G (1967) Olympic probe permits. Rand Daily Mail, 10 Feb: 1.

Olympic воYсотт (1968) Rand Daily Mail, 27 Feb: 12.

OLYMPIC OPPOSITION (1968) Rand Daily Mail, 8 Feb: 3.

OLYMPICS - SA KNOWS TONIGHT (1968) Rand Daily Mail, 15 Feb: 1.

OlYMPICS TALKS CALLED (1968) The Times, 2 Mar: 1.

Personal IntervieW, Harry EdWARds, 4 ApriL 2018, University Park, PA.

Press Conference Given by Mr. Avery Brundage, President of the InTERnational Olympic CommitTeE At GRenoble (1968) IOC Newsletter, No. 5, 16 Feb: 51-54.

ReUters (1968) Soviet asks I.O.C. to bar South Africa. The New York Times, 6 Mar: $54 \mathrm{~L}$.

S. Africa PLedges MIXed GameS teAm (1967) Daily Nation, 9 May: 25.

S.A. BACK IN GAMES (1968) Rand Daily Mail, 16 Feb 1968: 1.

S.A. 'YeS' ON FIVE POINTS (1968) Rand Daily Mail, 16 Feb: 1.

SANROC WILL DO ALL IT CAN TO BLOCK SA (1968) Rand Daily Mail, 16 Feb: 1.

SAPA-REUTER-A.P (1968) Ethiopia quits Olympics: But I.O.C. Chief claims victory. Rand Daily Mail, 17 Feb: 1.

SOVIET PRESENTS BID FOR 1976 GAMES (1969) The New York Times, 19 December: 79. The International Olympic Committee (1968) Newsletter - International Olympic Committee, No. 4(Jan): 7-17.

About the SOUth African team (1968) Newsletter - International Olympic Committee, No. 5 (Feb): 66-69.

THE POLITICS OF SPORT (1968) Rand Daily Mail, 16 Feb: 5 US ATHLETES PROTEST ON SA ROLE (1968) Rand Daily Mail, 9 February: 13.

WILT, LUKe AMONG 60 [SIC] ATHLETES SUPPorting BOYCOtT (1968) Philadelphia Tribune, 16 April: 15 


\section{Secondary sources:}

ALEGI P (2004) Laduma! Soccer, politics and society in South Africa. Scottsville: University of KwaZulu-Natal Press.

Alegi P AND Bolsmann C (2010) From apartheid to unity: White capital and black power in the racial integration of South African football, 1976-1992. African Historical Review 42: 1-18. https://doi.org/10.1080/17532523.2010.483783

ARCHER R AND BOUILLON A (1982) The South African game: sport and racism. London: Zed Press.

BLACK D AND NAURIGHT J (1998) Rugby and the South African nation. Manchester: Manchester University Press.

BLACKMAN D (2012) African Americans, pan-Africanism, and the anti-apartheid campaign to expel South Africa from the 1968 Olympics. The Journal of Pan African Studies 5(3): 1-25.

Bolsmann C (2010) White football in South Africa: Empire, apartheid and change, 1892-1977. Soccer and Society 11: 29-45. https://doi. org/10.1080/14660970903331318

Bolsmann C (2013) Professional football in apartheid South Africa: leisure, consumption and identity in the National Football League, 1959-1977. International Journal of the History of Sport 30: 1947-1961. https://doi.org/10 .1080/09523367.2013.861128

Воотн D (1997) The South African Council on Sport and the political antinomies of the sports boycott. Journal of Southern African Studies 23(1): 51-66. https:// doi.org/10.1080/03057079708708522

Воотн D (1998) The race game: sport and politics in South Africa. London: Frank Cass.

Воотн D (2003) Hitting apartheid for six? The politics of the South African sports boycott. Journal of Contemporary History 38(3): 477-493. https://doi. org/10.1177/0022009403038003008

BREWSTER C AND BREWSTER K (2010) Representing the nation: sport and spectacle in post-revolutionary Mexico. London: Routledge.

BRICKHILL J (1976) Race Against race: South Africa's 'multi-national' sport fraud. London: International Defence and Aid Fund.

BRUTUS D (1959) Sports test for South Africa. Africa South 3(4): 35-39.

CANTELON H AND MCDERMOTT L (2001)Charisma and the rational-legal organization: a case study of the Avery Brundage - Reginald Honey correspondence leading up to the South African expulsion From the International Olympic Movement. Olympika: The International Journal of Olympic Studies 10: 33-57.

CHARITAS P (2015) Imperialisms in the Olympics of the Colonization in the Postcolonization: Africa into the International Olympic Committee, 1910-1965. 
The International Journal of the History of Sport 32 (7) 909-922. https://doi. org/10.1080/09523367.2015.1027153

CORNELISSEN S (2011) Resolving 'the South Africa Problem': transnational activism, ideology and race in the Olympic movement, 1960-91. International Journal of the History of Sport 28(1): 153-169. https://doi.org/10.1080/09523367.2 011.525312

DESAI A, VISHNU P, KRISH R AND GOOLAM V (2002) Blacks in whites, a century of cricket struggles in KwaZulu-Natal. Pietermaritzburg: University of Natal Press.

De Broglio C (1970) South Africa: racism in sport. London: Christian Action Publications.

ESPY R (1981) The politics of the Olympic Games: with an epilogue, 1976-1980. Berkeley: University of California Press.

GeMmeLLJ (2004)The politics of South African cricket. London: Routledge. https:// doi.org/10.4324/9780203505892

GRUNDLINGH A, ODENDAAL A AND SPIES B (1995) Beyond the tryline: rugby and South African society. Johannesburg: Raven Press.

Guttmann A (1984) The games must go on: Avery Brundage and the Olympic Movement. New York: Columbia University Press.

HaIn P (1971) Don't play with apartheid: The Background to the Stop the Seventy Tour Campaign. London: George Allen and Unwin.

JARVIE G (1985) class, race and sport in South Africa's political economy. London: Routledge \& Kegan Paul.

JUDAH T (2009) Bikila: Ethiopia's barefoot Olympian. Reportage Press.

KeECHM(2001)Theties that bind: South Africa and sports diplomacy,1958-1963. The Sports Historian 21(1): 71-93. https://doi.org/10.1080/17460260109443377

KeECH M AND B HouliHAN (1999) Sport and the end of apartheid. The Round Table 88(349): 109-121. https://doi.org/10.1080/003585399108306

KIDD B (1988) The campaign against sport in South Africa. International Journal 43: 643-64. https://doi.org/10.1177/002070208804300406

MACINTOSH D AND HAWES M (1992) The IOC and the world of interdependence. Olympika: The International Journal of Olympic Studies (1): 29-45.

MuRRAY B AND MerRetT C (2004) Caught behind: race and politics in springbok cricket. Johannesburg: Wits University Press.

NAURIGHT J (1997) Sport, cultures and identities in South Africa. London: Leicester University Press.

NixON R (1992) Apartheid on the run: the South African sports boycott. Transition (58): 68-88 . https://doi.org/10.2307/2934968 
ODENDAAL A (2003) The story of an African game: black cricketers and the unmasking of one of cricket's greatest myths, South Africa, 1850-2003. Cape Town: David Phillip.

'OLYMPIC ChARTER' (n.d.) IOC website. <www.stillmed.olympic.org/Documents/ olympic_charter_en.pdf>

RAMBALI P (2006) Barefoot runner: the life of marathon champion Abebe Bikila. London: Serpent's Tail.

RAMSAMy S (2004) Reflections on a life in sport. Cape Town: Greenhouse.

SMIT J (2011) Dennis Brutus: activist for non-racialism and freedom of the human spirit. Alternation 17(2): 8-71.

SMIтH M (2006) Revisiting South Africa and the Olympic Movement: the correspondence of Reginald S. Alexander and the International Olympic Committee, 1961-86. The International Journal of the History of Sport 23(7): 1193-1216. https://doi.org/10.1080/09523360600832478 